\title{
Innovation processes in family firms: the relevance of organizational flexibility
}

\section{Wouter Broekaert, Petra Andries \& Koenraad Debackere}

\section{Small Business Economics}

An Entrepreneurship Journal

ISSN 0921-898X

Small Bus Econ

DOI 10.1007/s11187-016-9760-7

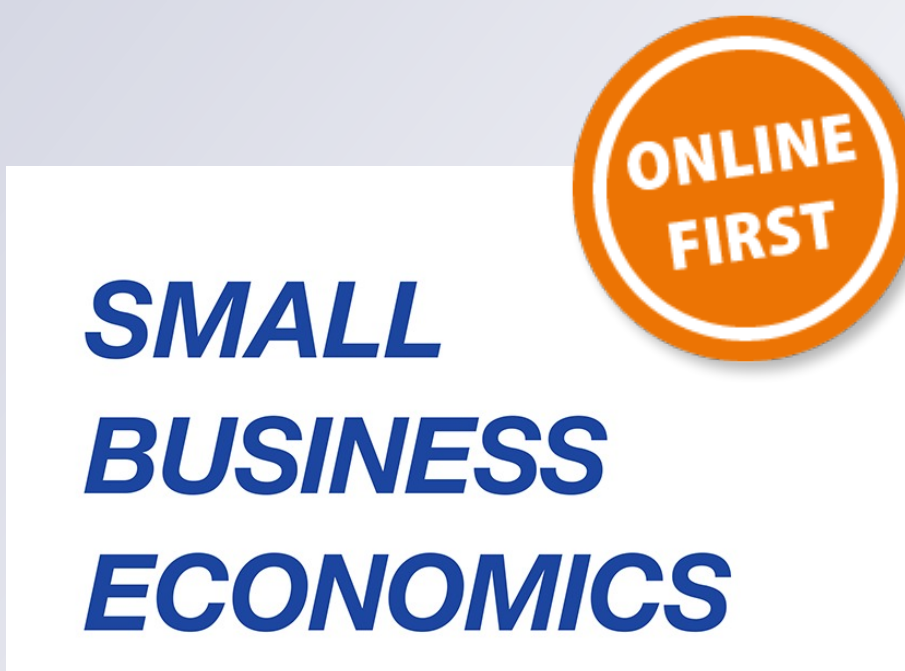

An Entrepreneurship Journal

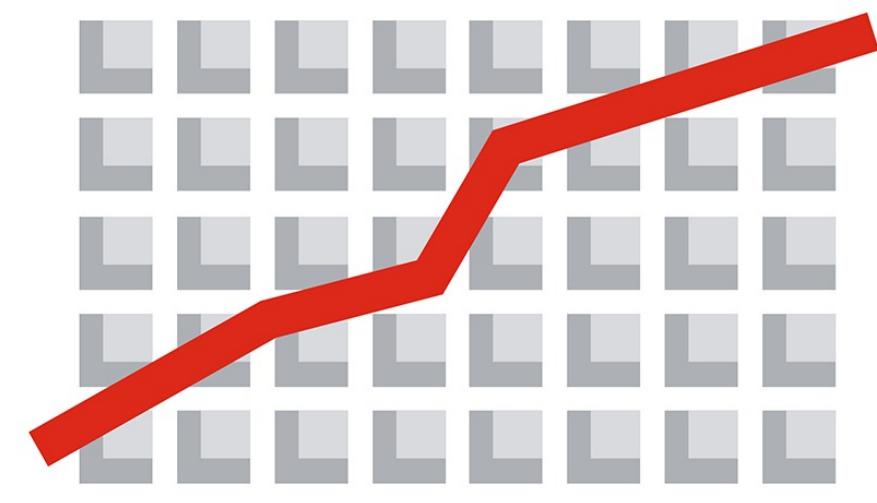

Volume 47 No. 1 June 2016

ISSN 0921-898X

\section{包 Springer}


Your article is protected by copyright and all rights are held exclusively by Springer Science +Business Media New York. This e-offprint is for personal use only and shall not be selfarchived in electronic repositories. If you wish to self-archive your article, please use the accepted manuscript version for posting on your own website. You may further deposit the accepted manuscript version in any repository, provided it is only made publicly available 12 months after official publication or later and provided acknowledgement is given to the original source of publication and a link is inserted to the published article on Springer's website. The link must be accompanied by the following text: "The final publication is available at link.springer.com". 


\title{
Innovation processes in family firms: the relevance of organizational flexibility
}

\author{
Wouter Broekaert • Petra Andries • \\ Koenraad Debackere
}

Accepted: 7 June 2016

(C) Springer Science+Business Media New York 2016

\begin{abstract}
The current study attempts to broaden our understanding of the processes underlying successful innovation in family firms by studying not only research and development (R\&D) but also organizational flexibility as drivers of innovation performance. Building on existing theoretical and empirical work, we formulate hypotheses on the relationship between family ownership and R\&D and organizational flexibility, and on how this translates into successful innovation. Using a sample of 2604 firms and 3140-year observations, we find that family firms engage less in $R \& D$, but are more flexible in the way they organize and that this organizational flexibility enables them to successfully develop new products and even outperform non-family owned businesses when it comes to process innovation. This research
\end{abstract}

W. Broekaert $(\bowtie)$

Department of Business Science, Research Center for Entrepreneurship Odisee (SVO), KU Leuven Association, Warmoesberg 26, 1000 Brussels, Belgium

e-mail: wouter.broekaert@odisee.be

\section{P. Andries}

Faculty of Economics and Business Administration, Ghent University, Tweekerkenstraat 2, 9000 Ghent, Belgium

e-mail: Petra.Andries@UGent.be

\section{K. Debackere}

KU Leuven Research and Development, KU Leuven, Minderbroedersstraat 8A, Box 5105, 3000 Louvain, Belgium

e-mail: koenraad.debackere@kuleuven.be contributes to the family business field by disentangling R\&D and organizational flexibility as processes underlying the relationship between family ownership and innovation performance. It illustrates how family firms' organizational flexibility can result in an innovation advantage and thereby has important implications for practitioners.

Keywords Family firm - Organizational flexibility · Innovation $\cdot R \& D$

JEL Classifications $\quad$ D23 $\cdot$ L22 $\cdot$ O32

\section{Introduction}

Management and economics scholars are increasingly paying attention to the family firms' innovative performance (De Massis et al. 2013). Whereas the successful development of new products and processes is deemed crucial for firms' long-term performance, innovation is inherently risky and uncertain (Shi 2003). As Classen et al. (2014) point out, these characteristics of innovation may have specific implications for family owned firms (Zellweger 2007; Miller et al. 2011) and several studies investigated whether family firms have a higher innovation performance than non-family owned firms. Unfortunately, the results are rather inconclusive, with some studies finding a positive (e.g., Craig and Dibrell 2006; 
Ayyagari et al. 2011), and others a negative relationship between family ownership and innovation performance (e.g., Block et al. 2013; Chin et al. 2009). Classen et al. (2014) show that family SMEs outperform non-family SMEs regarding process innovation outcomes-but not product innovation outcomeswhen controlling for innovation expenditures. Why this is the case is unclear as few studies explicitly investigated the different processes that enable family firms to successfully innovate.

In fact, research on determinants of family firms' innovative performance is mainly restricted to their research and development (R\&D). As De Massis et al. (2013) show, most empirical studies find that family firms invest less in R\&D than non-family owned firms. This is puzzling, as it appears to contradict the empirical findings of superior innovation performance in the studies mentioned above. One possible explanation is that studies of family firms' engagement in R\&D—which focus mostly on large, publicly traded enterprises (Classen et al. 2014) — are biased and that the average family firm does not have an $R \& D$ disadvantage. Another possibility is that family firms compensate their R\&D disadvantage through other processes.

The current study intends to broaden our understanding of the processes underlying successful innovation in family firms by studying both $R \& D$ and organizational flexibility, which we define in this paper as a firm's ability to adapt its internal organizational structure or the organization of its external relations, as drivers of innovation performance. These two underlying processes appear particularly interesting as existing literature suggests that family firms and non-family firms may differ in their ability to develop them. In fact, one can argue that some organizational processes stimulating innovation and organizational flexibility may be different for family firms and nonfamily firms (Hatum and Pettigrew 2004).

Building on existing theoretical and empirical work, we formulate hypotheses on the relationship between family ownership and R\&D and organizational flexibility, and on how these translate into innovation output. Using a sample of 2604 firms and 3140-year observations, we find that the average family firm engages less in $R \& D$ activities, but is more flexible in the way it organizes. This organizational flexibility allows family firms to attain similar product innovation performance levels and even to outperform their non-family counterparts with respect to successful new process development.

This research contributes to the family business field by extending the literature on innovation in family firms. In particular, it demonstrates that not only R\&D but also organizational flexibility underlies the relationship between family ownership and innovation performance. Furthermore, this paper responds to the call for additional research into how family firms' specific processes can result in a competitive advantage (Astrachan 2010), as it shows that family firms are particularly strong in flexibly adapting their organizational structure, giving them an advantage when it comes to developing process innovations. Our research has important implications for business families and family firm managers as it encourages them to continue reconfiguring and enhancing their internal and external organization. It demonstrates that $\mathrm{R} \& \mathrm{D}$ is not the only road to innovation and renewal and that family firms' most efficient choices are not necessarily the same as those of non-family owned firms.

\section{Literature background}

\subsection{R\&D and organizational flexibility as underlying processes for innovation}

Before exploring the relationship between family firms, R\&D and organizational flexibility, we clarify the impact of both R\&D and organizational flexibility on innovation performance. $R \& D$ activities are generally regarded as one of the main determinants of companies' innovative performance. As Eisenhardt and Martin (2000, p.1107) explain, R\&D routines "by which managers combine their varied skills and functional backgrounds [...] create revenue-producing products and services". R\&D is not the only possible or even a necessary road to innovation, but with $R \& D$ activities as an important enabler of technological innovation, a direct (though not necessarily immediate) positive effect of $R \& D$ on a company's innovation performance can be expected (Pakes and Griliches 1980). Even from the perspective of open innovation and innovation though external cooperation, internal R\&D remains important. After all, a company's internal capabilities generate the absorptive capacity required to turn externally acquired knowledge into 
innovation (Rosenberg 1990; Spithoven et al. 2010). This brings us to our first confirmatory hypothesis:

H1 There is a positive relationship between a firm's $\mathrm{R} \& \mathrm{D}$ activities and its innovation performance.

Although $\mathrm{R} \& \mathrm{D}$ is an important driver of innovation performance, other processes may be equally crucial. In particular, we argue that organizational flexibility, i.e., a firm's ability to adapt its internal organizational structure or the organization of its external relations, is crucial for renewal. Firstly, for a company to continuously innovate, it should have the flexibility to change its internal structure and decision-making processes (Miles et al. 2010). Whereas earlier strands in the literature focused on finding the most appropriate structure for stimulating innovation, more recently the understanding has emerged that there is no "one best" organizational structure for innovation (Raynor and Ahmed 2013). Instead, which structure is most helpful may depend on environmental variables, on the kind of innovation that is desired (Kelley 2009; Calantone et al. 2010), and even on the specific phase in the innovation process (Freeman and Engel 2007). Secondly, organizational flexibility also pertains to the organization of a firm's external relations. Cooperation with external partners can yield external ideas (Birkinshaw et al. 2008) but to be fully efficient, such cooperation needs an appropriate organizational framework that manages these relationships and integrates the external inputs (Teece et al. 1997). Furthermore, different external partners stimulate different types of innovations. For example, whereas collaborations with customers and suppliers help achieve incremental product innovations, collaborations with universities and research organizations are more useful for radical product innovation (Faems, Van Looy and Debackere 2005).

Clearly, companies continuously need to adapt both their internal organization and the organization of their external relations to innovate successfully. Therefore, a firm's ability to implement a specific organizational form may be less important than its ability to switch from one form to another and back again, which brings us to our second confirmatory hypothesis:

H2 There is a positive relationship between a firm's organizational flexibility and its innovation performance.

\subsection{Family firms and R\&D activities}

Family ownership can be expected to have an important impact on R\&D activities. On the one hand, it is widely believed that family firms engage less in R\&D activities than their non-family owned counterparts. There are two theoretical arguments to support this. Firstly, family firms often use different success or performance measures than non-family firms. Their goals are also targeted at value creation for the family, family harmony and maintaining the continuity of family control over the firm (Berrone et al. 2012). Such objectives may lead to a preference of paying out profits to family members over re-investing them in the business or in R\&D (Miller et al. 2011). Moreover, a focus on family well-being and continuity may also lead to risk aversion and therefore decreased $R \& D$ spending (Chen and Hsu 2009).

Whether due to different long-term priorities or risk aversion, many empirical studies find engagement in R\&D to be lower for family firms than for non-family firms (Muñoz-Bullón and Sanchez-Bueno 2011; Block 2012; Chrisman and Patel 2012), although there are significant differences within family firms, depending on the family firm definition used (Block 2012) and on the family generation in control (Beck et al. 2011).

On the other hand, many authors argue that family firms may be more inclined to engage in $R \& D$ than non-family firms, as they typically adhere to long-term goals (Zellweger 2007). In the presence of long-term family firm goals, such as transferring family control over the firm to the next generations, families may accept higher risks and hence higher levels of $R \& D$ activities (Chrisman and Patel 2012). Additionally, maintaining family control over the company when faced with increasing buyer or supplier power may necessitate a higher level of R\&D activities (Kotlar et al. 2014a; Kotlar et al. 2014b). Likewise, industries with a high potential for growth may prompt family firms to focus more on R\&D than non-family firms to secure their long-term viability and control over the company (Choi et al. 2015).

Moreover, even family firms with short-term orientation may decide to invest heavily in $R \& D$. When family firms are faced with disappointing company results, they tend to invest more in $R \& D$ than nonfamily firms do in an effort to return to a satisfactory performance level or to secure the firm's 
competitiveness (Chrisman and Patel 2012, Kotlar et al. 2014a). More specifically, families tend to prefer exploitative $R \& D$ activities when their firm is doing well, but they focus more on risky, exploratory R\&D when times are rough (Patel and Chrisman 2014). A related factor that mitigates the family's risk assessment is what portion of the family's overall wealth is invested in the family firm. When only a small part of that wealth depends on the firm's performance, the controlling family may be more willing to undertake risky $R \& D$ activities (Sciascia et al. 2015).

All in all, family managers' long-term horizon may be a more important consideration than risk aversion. This could lead to higher levels of actual R\&D activities in family firms, even though that may not always be apparent from the company's annual reports since many family managed firms tend to downplay the importance of their R\&D processes, possibly in an effort not to deter potential external investors (Schmid et al. 2014).

Clearly the literature offers arguments both for and against family firms' ability to engage in R\&D. However, taking into account the empirical evidence showing a negative link, we hypothesize:

H3 There is a negative relationship between a firm's level of family ownership and its R\&D activities.

\subsection{Family firms and organizational flexibility}

An argument can be made that the family influence is a barrier to organizational flexibility. Strong bonds to the company or to certain parts of it can lead to a desire to preserve the status quo and to resist changes. Family traditions, especially when handed down across generations, may create strong path dependencies that inhibit the family firm's adaptability and thereby also its ability to innovate (Chirico and Salvato 2008; Chirico and Nordqvist 2010). Strong family members that cling to tradition may preserve a closed company culture that blocks new ideas and change (Hall et al. 2001). Safeguarding the previous generations' legacy may become the family firm's primary goal, making it nearly impossible for successors to change the company's course (Steier and Miller 2010). Likewise, successors may feel morally or financially obliged to follow in their parents' footsteps or they may feel it's the easiest way to get a job (Sharma and Irving 2005), possibly leading to organizational stasis.
On the other hand, one can also argue that family firms are especially endowed with organizational flexibility. Family firms may benefit from a tradition of innovation and flexibility that helps to strengthen their resolve to remain organizationally flexible throughout different generations (Hatum and Pettigrew 2004). Overall, family firms' innovation management tends to be more flexible and less formalized than is the case in non-family firms (De Massis et al. 2015b). One reason is that family firms can usually benefit from extensive and strong social capital resources, both internally and externally (Arregle et al. 2007). Such social capital includes not only a static repository of knowledge but also the management skills to disseminate and integrate it. Long-term and close intra-family cooperation can lead to more frequent and more in-depth discussion about company issues and processes. As a result, knowledge can be shared and integrated more efficiently between family members, increasing the family firms' ability to adapt its internal structures and external relations (Chirico and Salvato 2008), while mutual trust between family members can speed up decision making and further enhance a family firm's flexibility. Externally, family firms' social capital and keener communication skills may help explain their more externally oriented innovation approach (De Massis et al. 2015b). Such external cooperation entails family firms' increased exposure to a multitude of different perspectives and attitudes, making them more flexible and innovative (Chrisman et al. 2015b). Furthermore, their long-term orientation gives family firms the time and patience to build trust, which facilitates knowledge sharing among partners (Sirmon and Hitt 2003). Finally, families can boost their organizational flexibility further if they succeed in extending their own sense of commitment and group feeling to the non-family employees. Not only does this increase overall motivation but it also stimulates essential components of organizational flexibility like employee creativity and responsiveness to change (Reichers et al. 1997; Zahra et al. 2008).

In conclusion, there is a multitude of compelling arguments in favor of family firms' organizational flexibility, resulting in the fourth hypothesis:

H4 There is a positive relationship between a firm's level of family ownership and its organizational flexibility.

Figure 1 visualizes our hypothesized model. 
Fig. 1 Hypothesized path model

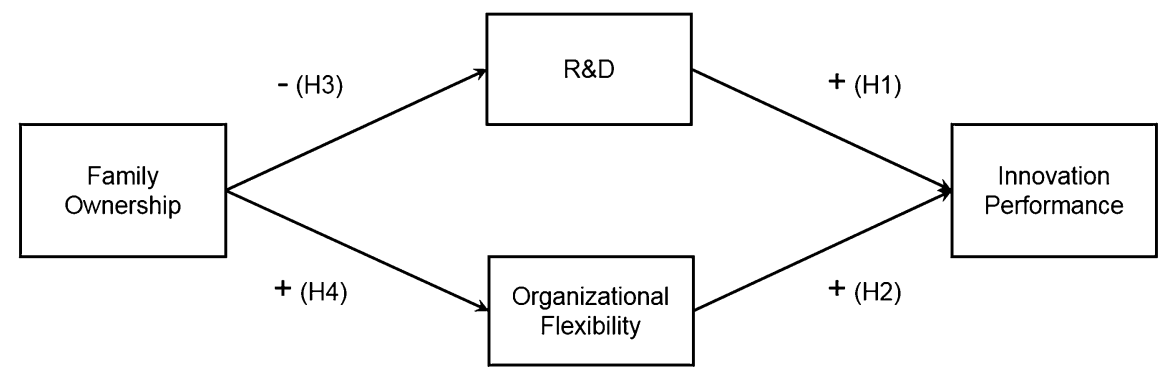

\section{Data collection and analysis}

\subsection{Sample and data collection}

We combined two consecutive waves of the Community Innovation Survey (CIS) conducted in Flanders. The CIS is an official survey of the European Commission and Eurostat and conducted in several European Union Member States. It develops insights into private organizations' innovative behavior. The use of CIS data has a long-standing tradition in innovation economics (Cassiman and Veugelers 2002; Belderbos et al. 2004; Czarnitzki and Toole 2011) and recently also in management (Laursen and Salter 2006; Leiponen and Helfat 2010; Klingebiel and Rammer 2014).

The Flemish CIS is a stratified (according to sector and size class) random sample that complies with the guidelines and definitions of the Oslo Manual (OECD 2005) for surveys on innovation activities and covers both production and service firms. Each year, several questions not included in the standard CIS instrument are added to the Flemish CIS for academic research, such as the items on family ownership used in this article.

The CIS5 wave, conducted in 2009 and reporting on the period 2006-2008, contacted a representative sample of 4969 firms and received 2202 responses (44\%). The CIS6, conducted in 2011 with data from 2008 to 2010, contacted 6493 firms for 3100 responses (48\%). After merging these two consecutive waves of the CIS survey and eliminating data due to missing values, our final sample contained 2604 firms and 3140-year observations.

\subsection{Variables and descriptive statistics}

Table 1 provides an overview of the descriptive statistics and correlations of the variables used in our analysis.

\section{(a) Family ownership}

When categorizing firms as family or non-family firms, we are constrained by the information available in the CIS. Although the CIS gathers data on family ownership, it does not contain information about the family's management or board presence. Therefore, we limit ourselves to an ownership-based definition of family firms. In line with previous research (LópezGracia and Sánchez-Andújar 2007; Feito-Ruiz and Menéndez-Requejo 2010; Ben-Amar et al. 2013, among others), we use the percentage of company shares owned by one person or one family during the period $t-2$ to $t$ to distinguish four categories. A value of 0 indicates that there is no main family shareholder. The variable takes the value of 1 when one person or family owns between 0 and $25 \%$ of all shares, the value of 2 for $25-49 \%$ and the value of 3 when one person or family owns at least $50 \%$ of the company's shares.

Our sample contains mostly firms that have either no family ownership (44\%) or at least $50 \%$ family ownership (48\%). Additionally, 5 and $3 \%$ of the firms in the sample report a family ownership of less than $25 \%$ or between 25 and $50 \%$, respectively.

\section{(b) R\&D activities}

In line with previous work (e.g., Czarnitzki and Kraft 2010), we represent the firm's R\&D activities by 


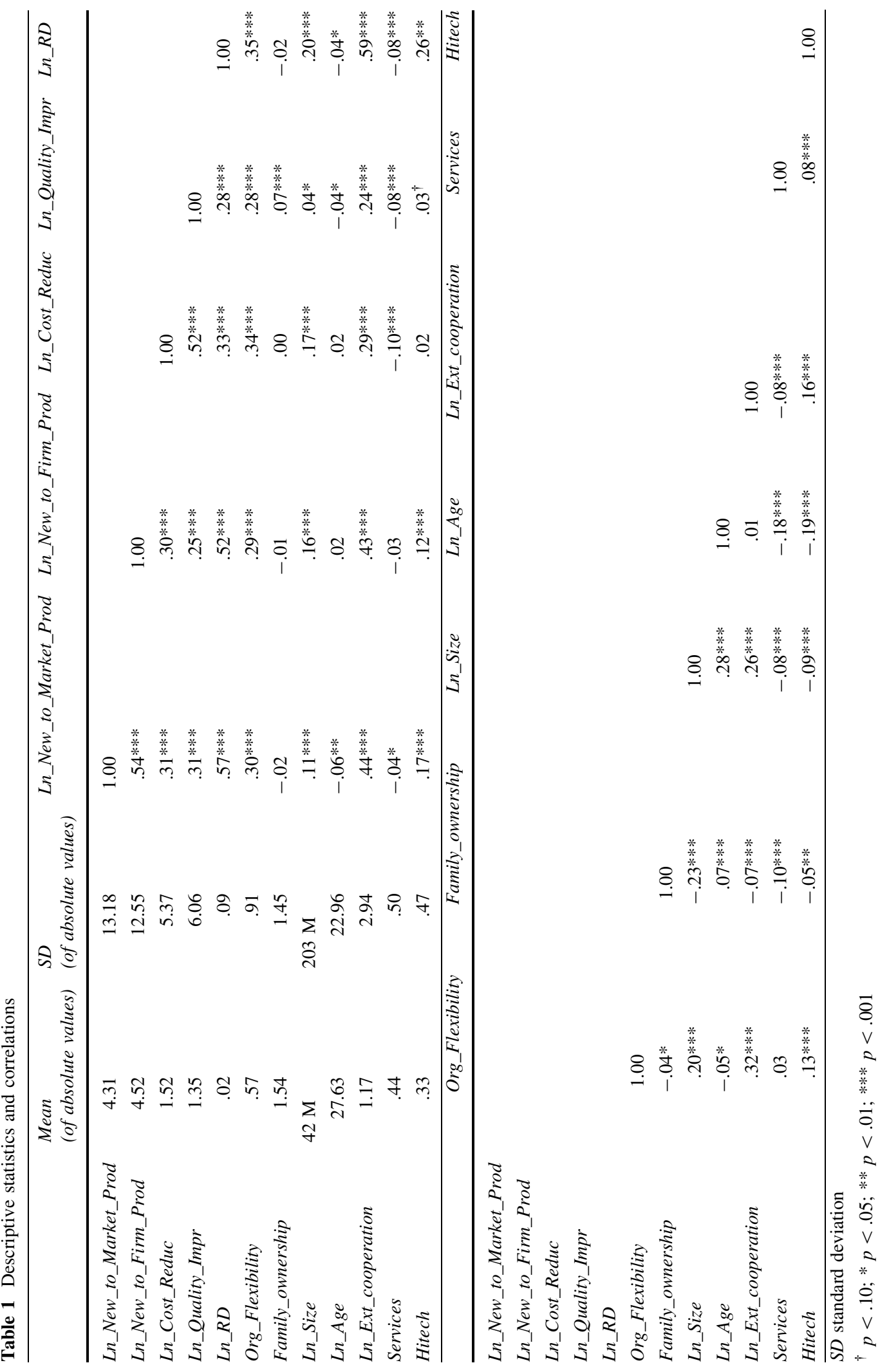


including the variable $R D$ and measured as the firm's internal $\mathrm{R} \& \mathrm{D}$ expenditures in year $t$ divided by its turnover in year $t$. Due to its skewed distribution, we transformed this variable by taking the natural logarithm of $\{1+R D\}$ and labeled it $L n \_R D$.

As is evident from Table 1, the average firm in our sample spends about $2 \%$ of its total turnover on R\&D. A more detailed look into the sample shows that only $31 \%$ of the firms engage in any $R \& D$ activities.

\section{(c) Organizational flexibility}

To measure organizational flexibility, we analyze whether the company has introduced "new business practices for organizing tasks or procedures," "new methods for organizing responsibilities and powers of decision within the enterprise" or "new methods for organizing the external relations with other companies or public institutions" during the period $t-2$ to $t$. We sum the three binaries to get one indicator for organizational flexibility and label the variable Org_Flexibility. ${ }^{1}$ The average firm in our sample scores 0.57 on this measure.

\section{(d) Innovation performance}

We used four alternative variables representing both product and process innovation performance.

For product innovation performance, we followed previous work (Faems et al. 2005; Laursen and Salter 2006), measuring product innovation success as product innovations' share in total sales. We distinguished between new to the market and new to the firm product innovation. New_to_Market_Prod measures the successful development and commercialization of radically new products or services as the share of turnover in year $t$ from goods and services that were

\footnotetext{
1 Although our measure shares similarities with process innovation, it is important and relevant to distinguish the two as this yields a more nuanced and complete approach to the study of innovation. Both the CIS survey and the Oslo Manual go to considerable lengths to explicitly explain the difference between organizational flexibility (which CIS labels 'organizational innovation') and process innovation. Among other things, the Oslo Manual notes that "A starting point for distinguishing process and/or organizational innovations is the type of activity: process innovations deal mainly with the implementation of new equipment, software and specific techniques or procedures, while organizational innovations deal primarily with people and the organization of work." (OECD 2005, p. 55). Additionally, the survey respondents are presented with extensive definitions and examples.
}

new to the market and were introduced during the period $t-2$ to $t$. The average firm in the sample obtained $4.32 \%$ of its turnover from such radically new goods and services. Similarly, New_to_Firm_ Prod represents the successful development and commercialization of new to the firm product or service innovations and is measured as the share of turnover from goods and services that were new to the firm but that were already available on the market and that were introduced during the period $t-2$ to $t$. The average firm in the sample obtained $4.53 \%$ of its turnover from new to the firm innovations. Both New_to_Market_Prod and New_to_Firm_Prod are represented as a percentage of total company turnover in year $t$.

With respect to process innovation success, we measured both the cost and quality implications of process innovations (OECD 2005). Cost_Reduc is the percentage average cost reduction per unit in year $t$ due to process innovations that were introduced during the period $t-2$ to $t$. Quality_Impr is the percentage turnover increase in year $t$ due to quality improvements (of the production process) resulting from process innovations introduced during the period $t-2$ to $t$. The average firm in the sample obtained a cost reduction of approximately $1.52 \%$ per unit produced due to process innovations. It had an average turnover increase of about $1.35 \%$ due to process innovation.

Because of skewed distributions, we added 1 to all values (to avoid zero values) and then took their natural logarithm when entering them into our analyses. We labeled those variables Ln_New_to_Market_Prod, Ln_New_to_Firm_Prod, Ln_Cost_Reduc and Ln_Quality_Impr.

\section{(e) Control variables}

External cooperation A higher diversity of external partners can help a company remain innovative (Duysters and Lokshin 2011). The CIS questionnaires ask each company to indicate whether it cooperates with each of 7 different partner categories (i.e., suppliers, customers, universities), into four possible geographical categories, resulting in a $7 \times 4$ answer matrix. We obtain our external cooperation variable by summing all binary scores and applying a logarithmic transformation.

Size Several theoretical arguments substantiate potential innovative advantages of both small and 
large firms (Acs and Audretsch 1990). To control for a company's size, we added the natural logarithm of the turnover in year $t$ to our model.

Age The firm's age is also used as a control variable, as younger firms may be more innovative than older ones (Schneider and Veugelers 2010). For the path analysis, we used the natural logarithm of $\{1+$ the firm's age \}.

Industry The literature indicates an industry effect on both innovation and innovation success (Spithoven et al. 2010). We use the companies' main NACE code to create a first industry dummy, distinguishing manufacturing firms from service firms. Based on the sector's average $R \& D$ intensity ( $R \& D$ expenditures/value added), Eurostat also classifies the NACE codes into high tech, medium-high tech, medium-low tech and low tech sectors. Our second industry dummy distinguishes between high tech (high tech or medium-high tech) and low tech companies (medium-low tech or low tech).

\section{Results}

Given the complexity of our hypothesized model and the need to analyze multiple regressions simultaneously, we use a path analysis approach. As we have a large sample, we use Browne's asymptotically distribution-free (ADF) estimation method to counter estimation problems that may result from the nonnormality of some of our (categorical) variables (Norman and Streiner 2003). Since we want to distinguish between four different variables measuring specific innovation performances, we analyze a total of four path models.
To assess how well the models fit the data, we evaluate some common goodness of fit indices. As can be seen in Table 2, both the goodness of fit index (GFI) of 0.9999 and the adjusted goodness of fit index (AGFI) with values between 0.9965 and 0.9985 lie well above the generally accepted cutoff point of 0.9 (Sharma 1996; Norman and Streiner 2003). Instead of using the GFI and the AGFI, in the case of the ADF method, $\mathrm{Hu}$ and Bentler (1998) recommend looking at alternatives like the Standardized Root-Mean-Square Residual (SRMR) and the Comparative Fit Index (CFI). Commonly accepted values to indicate a good fit are below 0.05 for the SRMR and above 0.95 for the CFI. Our models yield SRMR values between 0.007 and 0.01 and CFI values consistently over 0.99 .

Ideally, the Chi square value for the models should indicate non-significance, but such is not the case with our sample. However, as previously shown (Sharma 1996; Norman and Streiner 2003), the Chi square statistic easily becomes significant for large samples, even when there is no actual reason to question the model's fit. Therefore, and given the positive signal from the other goodness of fit indices, we do not reject our model.

Next, we analyze the relationships between our main variables, as hypothesized in the literature section, by looking at the standardized results of the four models. As shown in Table 3, all models reveal a significant negative relationship between Family_ownership and $L n \_R D$, confirming hypothesis 3 . However, the results concerning the relationship between $L n \_R D$ and innovation performance are less uniform. Although we find the expected positive link between $L n \_R D$ and both product innovation

Table 2 Goodness of fit measures for different models

(1)

\begin{tabular}{|c|c|c|c|c|}
\hline Goodness of fit index (GFI) & 1.00 & 1.00 & 1.00 & 1.00 \\
\hline Adjusted goodness of fit index (AGFI) & 1.00 & 1.00 & 1.00 & 1.00 \\
\hline Standardized root-mean-square residual (SRMR) & .01 & .01 & .01 & .01 \\
\hline Bentler comparative fit index (CFI) & 1.00 & 1.00 & 1.00 & .99 \\
\hline Chi square & 7.68 & 7.52 & 7.57 & 18.09 \\
\hline Degrees of freedom & 2.00 & 2.00 & 2.00 & 2.00 \\
\hline $\operatorname{Pr}>$ Chi square & .02 & .02 & .02 & .00 \\
\hline Akaike information criterion (AIC) & 93.68 & 93.52 & 93.57 & 104.09 \\
\hline
\end{tabular}

(1) Ln_New_to_Market_Prod model, (2) Ln_New_to_Firm_Prod model, (3) Ln_Cost_Reduc model, (4) Ln_Quality_Impr model 
Table 3 Standardized Path Coefficients and ( $t$ values)

\begin{tabular}{|c|c|c|c|c|}
\hline Path from $->$ to & (1) & (2) & (3) & (4) \\
\hline \multicolumn{5}{|l|}{ Direct effects } \\
\hline Family_ownership & $-0.05^{* *}$ & $-0.05 * *$ & $-0.05 * *$ & $-0.05 * *$ \\
\hline$->L n \_R D$ & $(-3.21)$ & $(-3.21)$ & $(-3.19)$ & $(-3.29)$ \\
\hline Ln_Size & $-0.13 * * *$ & $-0.13 * * *$ & $-0.13 * * *$ & $-0.13 * * *$ \\
\hline$->L n \_R D$ & $(-8.36)$ & $(-8.48)$ & $(-8.64)$ & $(-8.7)$ \\
\hline Ln_Age & -0.03 & -0.03 & -0.02 & -0.02 \\
\hline$->L n \_R D$ & $(-1.63)$ & $(-1.64)$ & $(-1.6)$ & $(-1.62)$ \\
\hline Ln_Ext_cooperation & $0.36 * * *$ & $0.36^{* * *}$ & $0.36 * * *$ & 0.36 *** \\
\hline$->L n \_R D$ & $(16.32)$ & $(16.41)$ & $(16.47)$ & $(16.52)$ \\
\hline Services & $0.12 * * *$ & $0.12 * * *$ & $0.12 * * *$ & $0.13 * * *$ \\
\hline$->L n \_R D$ & $(8.66)$ & $(8.75)$ & $(8.76)$ & $(8.8)$ \\
\hline Hitech & $0.17 * * *$ & $0.17 * * *$ & $0.17 * * *$ & $0.17 * * *$ \\
\hline$->L n \_R D$ & $(12.12)$ & $(12.24)$ & $(12.37)$ & $(12.45)$ \\
\hline Family_ownership & $0.04 *$ & $0.04 *$ & $0.04 *$ & $0.04 *$ \\
\hline$->$ Org_Flexibility & $(2.38)$ & $(2.39)$ & $(2.38)$ & $(2.33)$ \\
\hline Ln_Size & $0.16 * * *$ & $0.16^{* * *}$ & $0.16^{* * *}$ & $0.16^{* * *}$ \\
\hline ->Org_Flexibility & $(8.57)$ & $(8.61)$ & $(8.6)$ & $(8.46)$ \\
\hline Ln_Age & $-0.07 * * *$ & $-0.07 * * *$ & $-0.07 * * *$ & $-0.07 * * *$ \\
\hline$->$ Org_Flexibility & $(-3.84)$ & $(-3.84)$ & $(-3.91)$ & $(-3.85)$ \\
\hline Ln_Ext_cooperation & $0.28 * * *$ & $0.28 * * *$ & $0.28 * * *$ & $0.28 * * *$ \\
\hline ->Org_Flexibility & $(12.81)$ & $(12.95)$ & $(12.87)$ & $(12.96)$ \\
\hline Services & $0.05 * *$ & $0.05 * *$ & $0.05 * *$ & $0.05^{* *}$ \\
\hline ->Org_Flexibility & $(2.97)$ & $(3.02)$ & $(2.98)$ & $(2.94)$ \\
\hline Hitech & $0.08 * * *$ & $0.08 * * *$ & $0.08 * * *$ & $0.08 * * *$ \\
\hline ->Org_Flexibility & $(4.34)$ & $(4.36)$ & $(4.37)$ & $(4.41)$ \\
\hline$L n \_R D$ & $0.20 * * *$ & $0.10 * * *$ & -0.02 & 0.00 \\
\hline$->$ Innovation & $(6.76)$ & $(3.92)$ & $(-0.68)$ & $(0.09)$ \\
\hline Org_Flexibility & $0.16^{* * *}$ & $0.13 * * *$ & $0.25 * * *$ & $0.24 * * *$ \\
\hline -> Innovation & $(7.87)$ & $(6.81)$ & (11.98) & $(10.35)$ \\
\hline Ln_Size & -0.01 & 0.02 & $0.03^{\dagger}$ & $-0.09 * * *$ \\
\hline -> Innovation & $(-0.48)$ & $(1.25)$ & $(1.69)$ & $(-5.22)$ \\
\hline Ln_Age & $-0.04 *$ & 0.02 & -0.03 & $-0.04^{\dagger}$ \\
\hline$->$ Innovation & $(-2.35)$ & $(1.4)$ & $(-1.52)$ & $(-1.92)$ \\
\hline Ln_Ext_cooperation & $0.30 * * *$ & $0.30 * * *$ & $0.18 * * *$ & $0.14 * * *$ \\
\hline -> Innovation & (11.87) & $(12.63)$ & $(6.92)$ & $(5.3)$ \\
\hline Services & $-0.03 *$ & 0.00 & $-0.07 * * *$ & $-0.06^{* * *}$ \\
\hline -> Innovation & $(-2.33)$ & $(-0.26)$ & $(-3.9)$ & $(-3.54)$ \\
\hline Hitech & $0.05 * *$ & $0.03^{\dagger}$ & -0.03 & -0.02 \\
\hline -> Innovation & $(3.06)$ & $(1.96)$ & $(-1.53)$ & $(-0.98)$ \\
\hline \multicolumn{5}{|l|}{ Total effects } \\
\hline Family_ownership & -0.00 & 0.00 & $0.01 *$ & $0.01 *$ \\
\hline$->$ Innovation & $(-0.91)$ & $(0.04)$ & $(2.41)$ & $(2.13)$ \\
\hline
\end{tabular}

(1) Ln_New_to_Market_Prod model, (2) Ln_New_to_Firm_Prod model, (3) Ln_Cost_Reduc model, (4) Ln_Quality_Impr model ${ }^{\dagger} p<.10 ; * p<.05 ; * * p<.01 ; * * * p<.001$ 
Fig. 2 Standardized results
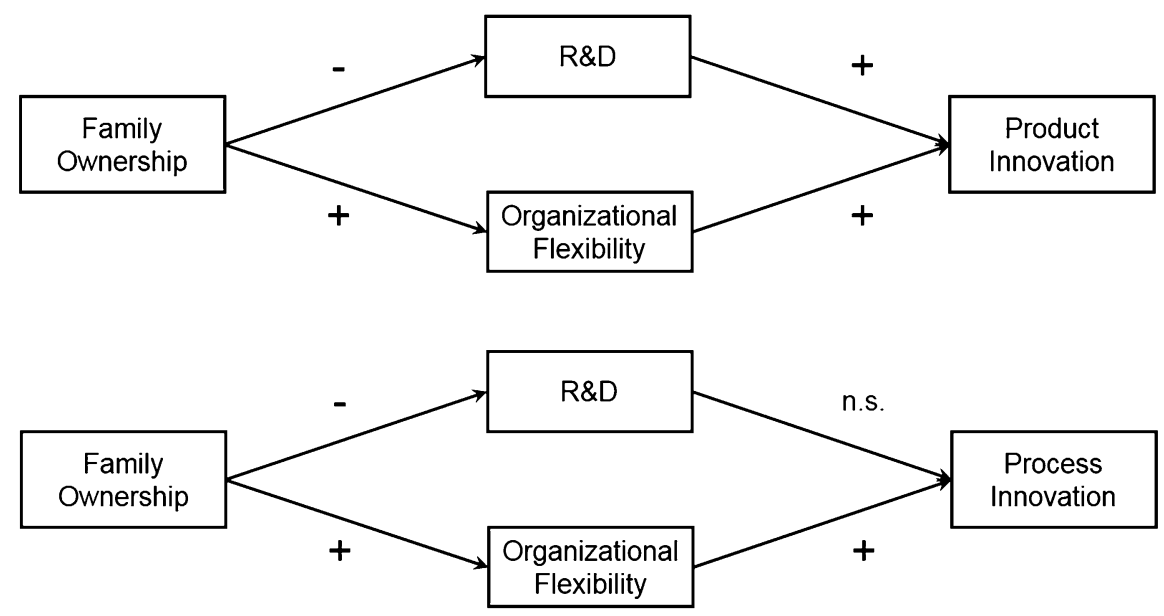

- : Significant negative relationship $(p<0.05)$

+ : Significant positive relationship $(p<0.05)$

n.s.: Not significant $(p \geq 0.05)$

outcomes New_to_Market_Prod (\%) and New_to_Firm_Prod (\%) (models 1 and 2 in Table 3), the links with process innovation performance measured as Cost_Reduc (\%) and Quality_Impr (\%) are not significant (models 3 and 4 in Table 3), thereby only partially supporting hypothesis 1 . Our analysis yields significant positive relationships between firms' level of Family_ownership and Org_Flexibility and between Org_Flexibility and all four innovation performance measures and be it related to product or process innovation. Hence, both hypotheses 4 and 2 are supported.

The overall, total effect of family ownership on innovation performance is significantly positive where process innovation is concerned (see the last row of Table 3). As for product innovation, Family_ownership has no significant overall effect on product innovation performance. Figure 2 shows the main results for our models.

\section{Discussion}

This study wanted to broaden our understanding of the processes underlying successful innovation in family firms by taking into account not only R\&D but also organizational flexibility. Firstly, our results confirm previous empirical evidence showing that family firms invest less in R\&D than other firms. Although several studies argued that family firms' long-term orientation may spur R\&D activities (Zellweger 2007), our findings support the contrasting argument that family firms' focus on value creation for the family, family harmony and continuity (Berrone et al. 2012), and the accompanying risk aversion (Naldi et al. 2007; Chen and Hsu 2009) will lead to decreased R\&D spending. However, this study also shows that the impact of this lesser $R \& D$ engagement on innovative performance is not at all straightforward. Whereas R\&D clearly stimulates eventual product innovation performance, it has little or no impact on process innovation. This may be due to the fact that product innovations are often developed internally and therefore depend on a company's internal knowledge and capabilities, while process innovations rely considerably more on external suppliers' input. ${ }^{2}$ Hence, this first finding indicates that family firms' innovative "handicap" due to their lower R\&D activity may be less pronounced than assumed in previous studies, as this lesser engagement in $\mathrm{R} \& \mathrm{D}$ does not affect their process innovation performance.

\footnotetext{
$\overline{2 \text { Whereas } 69} \%$ of the product innovators in our CIS6 subsample developed their product innovations without the help of external partners, this was only the case for $32 \%$ of the process innovators.
} 
Furthermore, our main finding indicates that family firms are actually better than non-family firms at flexibly changing their internal and external organization, which in turn leads to improved innovation performance. This supports our argument that family firms are especially endowed with organizational flexibility, possibly because (a) their focus on nonfinancial and long-term goals leads to a more dynamic attitude if they perceive innovation to be in their longterm interest, (b) mutual trust between family members speeds up decision making, improves knowledge exchange and enhances flexibility and (c) when the family succeeds in extending its own sense of commitment and group feeling to its non-family employees, this stimulates essential components of organizational flexibility like employee creativity and responsiveness to change.

We find that family firms' $R \& D$ disadvantage is in fact compensated by their organizational flexibility. This leads to similar product innovation performance as observed in non-family owned firms. Novel and recent research on new product development (NPD) projects in family firms leads to similar insights (De Massis et al. 2016). Among other things, the authors find that family firms' specific organizational characteristics allow employees to flexibly switch between the innovation project and their "normal" tasks and to achieve better NPD results than full-time crossfunctional innovation teams. At the same time such an approach keeps costs under control, effectively allowing those family firms to achieve better innovation performance with less $\mathrm{R} \& \mathrm{D}$ efforts by tailoring the design of their innovation process to their specific family firm characteristics.

Furthermore, as R\&D activities turn out to be less relevant for process innovation, family firms' advantage regarding organizational flexibility even allows them to outperform their counterparts when it comes to process innovation performance. Classen et al. (2014) already showed that family SMEs tend to outperform non-family SMEs regarding process innovation outcomes when controlling for innovation expenditures. Our findings complement those results by proposing that family firms' elevated organizational flexibility is at the basis of this outperformance and even more that R\&D activities are of little importance in this respect. As our results indicate that family firms' organizational flexibility grants them an advantage when it comes to the development of process innovations, this paper responds to the call for additional research into how family firms' specific processes can result in a competitive advantage (Astrachan, 2010). These insights reconcile the apparently contradicting results of previous empirical studies that family firms engage less in $R \& D$ than non-family owned firms, but display superior innovation performance.

We believe our research has important implications for future family firm research. By disentangling $R \& D$ and organizational flexibility as separate underlying processes of innovation performance and by distinguishing between product and process innovation performance, we paint a more nuanced and comprehensive picture of the relationship between family ownership and innovation, which can inform future research and theorizing on innovation in family firms. Firstly, our results demonstrate the clear necessity of distinguishing between product innovation and process innovation. Lumping together measures of product and process innovation performance may obscure the true processes and effects that are going on in family firms. Secondly, the study clearly demonstrates the need to move away from a focus on $R \& D$ activities, and in addition investigate other processes underlying innovation performance, specifically the ones concerning innovation management and organizational flexibility. Distinguishing between product and process innovation and the distinct processes underlying these specific innovation outcomes may help overcome and explain the inconsistencies of previous studies, thereby moving the field further forward. In this respect, the recently proposed Family Driven Innovation (FDI) framework (De Massis et al. 2015a) looks quite promising as it offers an integrated and detailed approach to analyzing family firm innovation. Specifically, the FDI framework emphasizes the need for family firms to achieve a fit between their unique characteristics as a family firm and the approach they take toward innovation. This means that they should strive for compatibility between their goals and motivations, their organizational structure and their available resources on the one hand and their choices on where to search for knowledge, how to manage the innovation process and what kind of innovation (e.g., product or process innovation) to pursue on the other hand (De Massis, et al., 2015a).

Our research has important implications for business families and family firm managers as the 
development of R\&D and organizational flexibility require significant investments of time and money. While this may be obvious for $R \& D$, also the cost implications of organizational flexibility and change have started to receive more attention. Changes require work to be diverted away from the company's existing business, creating opportunity costs. Organizational ecologists (Hannan and Freeman, 1989) and organizational scholars (Kotter 1995) argued that change is costly and complicated and can lead to firm failure (Barnett and Freeman, 2001), decreased market shares (Greve 1999) and employee turnover (Baron et al. 2001). Demonstrating that flexibly adapting their internal and external organization in fact helps family firms overcome their R\&D disadvantage and leads to successful product and process development and can strengthen family firms' resolve to look beyond these short-term costs. Our findings can hence encourage family owners to continue reconfiguring and enhancing their internal and external organization. Developing internal R\&D activities is not the only road to innovation and renewal, especially if the ultimate goal is process innovation. Family managers should realize that the most efficient choices for them are not necessarily the same as those for non-family owned firms.

\section{Limitations and suggestions for further research}

We acknowledge that this paper does not incorporate the cost implications of $R \& D$ and organizational flexibility and can therefore not provide any conclusions on their ultimate financial effects. It would be interesting to study this further, also distinguishing between different types of organizational changes, as it could help managers prioritize certain organizational changes. Furthermore, we acknowledge that the turnover and cost savings effects of $R \& D$ projects and organizational changes introduced during the period $t-2$ to $t$ may not fully materialize by time $t$. The timeframe in this study may hence be too short to fully grasp the positive effect of $R \& D$ and organizational flexibility. Thus, the current study may be underestimating their positive effects on innovation performance.

Finally, there are limitations regarding the measure we used to indicate the extent to which a company can be considered to be a family firm. The operationalization of family ownership in the CIS is rather limited. Further analyses could benefit from more detailed information about the family's influence in the firm. While family firms' typical ownership and control characteristics will give them a better ability to innovate than non-family firms, their specific goals and motivations may decrease their willingness to do so (Chrisman et al. 2015a). Thus, although family ownership as we measure it indicates family firms' ability to behave differently from non-family firms, a more accurate definition of family firms should also include willingness indicators (Chrisman et al. 2012; De Massis et al. 2014). Ownership and other demographic indicators of being a family firm should ideally be combined with essence indicators that more directly measure actual differences in behavior (Chua et al. 1999; Chrisman et al. 2005; Basco, 2013) to reveal greater variety within family firms. Moreover, information on family ownership should ideally be combined with information on the actual family management of the firm. Due to agency complications, managers with little or no ownership share have a different attitude toward R\&D than manager-owners (Czarnitzki and Kraft 2004; Beyer et al. 2012). Finally, it could be interesting to distinguish lone founder firms from other types of family firms to see whether our results hold for both groups (Miller et al. 2011).

In addition to including more detailed information about the family's influence in the firm, the field of family firm innovation may benefit from more indepth analyses of the relationships between specific strategic innovation decisions and various family firm characteristics. In particular, more research is needed into how family firms can achieve a good fit between their unique characteristics and the innovation options available to them (De Massis et al. 2015a). For example, further research could lead to more and better understanding of the positive link between family firms and organizational flexibility that we find in our study, as well yield more insight into how this flexibility can lead to better innovation performance. Which family firm goals, which organizational structures, which management methods or resources are most compatible with the desired level of flexibility? How does such flexibility impact the family firm's innovation process and eventually lead to product versus process or radical versus incremental innovation? Considering the nature of those research 
questions, we believe qualitative approaches will be most appropriate to advance our understanding of such complex processes.

\section{Conclusions}

The current study attempts to broaden our understanding of the processes underlying successful innovation in family firms by studying not only research and development $(R \& D)$ but also organizational flexibility as drivers of innovation performance. Building on existing theoretical and empirical work, we formulated hypotheses on the relationship between family ownership and R\&D and organizational flexibility, and on how these translate into successful product and process development. We found that family firms engage less in $R \& D$, but are more flexible in the way they organize and that this organizational flexibility enables them to successfully develop new products and even outperform non-family owned businesses when it comes to process innovation. The study contributes to the field of family businesses by substantiating the need to distinguish between product and process innovation performance and by demonstrating that not only R\&D but also organizational flexibility underlies these distinct innovation outcomes. It has important implications for business families and family firm managers as it highlights how family firms' organizational flexibility can result in an innovation advantage vis-à-vis non-family owned firms.

\section{References}

Acs, Z. J., \& Audretsch, D. B. (1990). Innovation and small firms. Cambridge: MIT Press.

Arregle, J.-L., Hitt, M. A., Sirmon, D. G., \& Very, P. (2007). The development of organizational social capital: Attributes of family firms. Journal of Management Studies, 44(1), 73-95. doi:10.1111/j.1467-6486.2007.00665.x.

Astrachan, J. H. (2010). Strategy in family business: Toward a multidimensional research agenda. Journal of Family Business Strategy, 1(1), 6-14. doi:10.1016/j.jfbs.2010.02. 001.

Ayyagari, M., Demirgüç-Kunt, A., \& Vojislav, M. (2011). Firm innovation in emerging markets: The role of finance, governance, and competition. Journal of Financial and Quantitative Analysis, 46(6), 1545-1580. doi:10.1017/ S0022109011000378.
Barnett, W. P., \& Freeman, J. (2001). Too much of a good thing? Product proliferation and organizational failure. Organization Science, 12(5), 539-558.

Baron, J. N., Hannan, M. T., \& Burton, M. D. (2001). Labor pains: Change in organizational models and employee turnover in young, high-tech firms. American Journal of Sociology, 106(4), 960-1012. doi:10.1086/320296.

Basco, R. (2013). The family's effect on family firm performance: A model testing the demographic and essence approaches. Journal of Family Business Strategy, 4(1), 42-66. doi:10.1016/j.jfbs.2012.12.003.

Beck, L., Janssens, W., Debruyne, M., \& Lommelen, T. (2011). A study of the relationships between generation, market orientation, and innovation in family firms. Family Business Review, 24(3), 252-272. doi:10.1177/0894486511409210.

Belderbos, R., Caree, M., Diederen, B., Lokshin, B., \& Veugelers, R. (2004). Heterogeneity in R\&D cooperation strategies. International Journal of Industrial Organization, 22(8, 9), 1237-1263. doi:10.1016/j.ijindorg.2004.08.001.

Ben-Amar, W., Francoeur, C., Hafsi, T., \& Labelle, R. (2013). What makes better boards? A closer look at diversity and ownership. British Journal of Management, 24(1), 85-101. doi:10.1111/j.1467-8551.2011.00789.x.

Berrone, P., Cruz, C., \& Gomez-Mejia, L. R. (2012). Socioemotional wealth in family firms: Theoretical dimensions, assessment approaches, and agenda for future research. Family Business Review, 25(3), 258-279. doi:10.1177/ 0894486511435355.

Beyer, M., Czarnitzki, D., \& Kraft, K. (2012). Managerial ownership, entrenchment and innovation. Economics of Innovation and New Technology, 21(7), 679-699. doi:10. 1080/10438599.2011.639978.

Birkinshaw, J., Hamel, G., \& Mol, M. J. (2008). Management innovation. Academy of Management Review, 33(4), 825-845. doi:10.5465/AMR.2008.34421969.

Block, J. H. (2012). R\&D investments in family and founder firms: An agency perspective. Journal of Business Venturing, 27(2), 248-265. doi:10.1016/j.jbusvent.2010.09.003.

Block, J., Miller, D., Jaskiewicz, P., \& Spiegel, F. (2013). Economic and technological importance of innovations in large family and founder firms: An analysis of patent data. Family Business Review, 26(2), 180-199. doi:10.1177/ 0894486513477454.

Calantone, R. J., Harmancioglu, N., \& Droge, C. (2010). Inconclusive innovation "returns": A meta-analysis of research on innovation in new product development. Journal of Product Innovation Management, 27(7), 1065-1081. doi:10.1111/j.1540-5885.2010.00771.x.

Cassiman, B., \& Veugelers, R. (2002). R\&D cooperation and spillovers: Some empirical evidence from Belgium. The American Economic Review, 92(4), 1169-1184. doi:10. 1257/00028280260344704.

Chen, H.-L., \& Hsu, W.-T. (2009). Family ownership, board independence, and R\&D investment. Family Business Review, 22(4), 347-362. doi:10.1177/0894486509341062.

Chin, C. L., Chen, Y. J., Kleinman, G., \& Lee, P. (2009). Corporate ownership structure and innovation: Evidence from Taiwan's electronics industry. Journal of Accounting Auditing Finance, 24(1), 145-175. doi:10.1177/0148558X0902400108.

Chirico, F., \& Nordqvist, M. (2010). Dynamic capabilities and transgenerational value creation in family firms: The role 
of organizational culture. International Small Business Journal, 28(5), 487-504. doi:10.1177/0266242610370402.

Chirico, F., \& Salvato, C. (2008). Knowledge integration and dynamic organizational adaptation in family firms. Family Business Review, 21(2), 169-181. doi:10.1111/j.17416248.2008.00117.x.

Choi, Y. R., Zahra, S. A., Yoshikawa, T., \& Han, B. H. (2015). Family ownership and R\&D investment: The role of growth opportunities and business group membership. Journal of Business Research, 68(5), 1053-1061. doi:10. 1016/j.jbusres.2014.10.007.

Chrisman, J. J., Chua, J., De Massis, A., Frattini, F., \& Wright, M. (2015a). The ability and willingness paradox in family firm innovation. Journal of Product Innovation Management, 32(3), 310-318. doi:10.1111/jpim.12207.

Chrisman, J. J., Chua, J. H., Pearson, A. W., \& Barnett, T. (2012). Family involvement, family influence, and familycentered non-economic goals in small firms. Entrepreneurship Theory and Practice, 36(2), 267-293. doi:10.1111/j.1540-6520.2010.00407.x.

Chrisman, J. J., Chua, J. H., \& Sharma, P. (2005). Trends and directions in the development of a strategic management theory of the family firm. Entrepreneurship Theory and Practice, 29(5), 555-575. doi:10.1111/j.1540-6520.2005. 00098.x.

Chrisman, J. J., Fang, H., Kotlar, J., \& De Massis, A. (2015b). A note on family influence and the adoption of discontinuous technologies in family firms. Journal of Product Innovation Management, 32(3), 384-388. doi:10.1111/jpim. 12206.

Chrisman, J. J., \& Patel, P. C. (2012). Variations in R\&D investments of family and nonfamily firms: Behavioral agency and myopic loss aversion perspectives. Academy of Management Journal, 55(4), 976-997. doi:10.5465/amj. 2011.0211.

Chua, J. H., Chrisman, J. J., \& Sharma, P. (1999). Defining the family business by behavior. Entrepreneurship Theory and Practice, 23(4), 19-39.

Classen, N., Carree, M., Van Gils, A., \& Peters, B. (2014). Innovation in family and non-family SMEs: An exploratory analysis. Small Business Economics, 42(3), 595-609. doi:10.1007/s11187-013-9490-z.

Craig, J., \& Dibrell, C. (2006). The natural environment, innovation, and firm performance: A comparative study. Family Business Review, 19(4), 275-288. doi:10.1111/j. 1741-6248.2006.00075.x.

Czarnitzki, D., \& Kraft, K. (2004). Management control and innovative activity. The Review of Industrial Organization, 24(1), 1-24.

Czarnitzki, D., \& Kraft, K. (2010). On the profitability of innovative assets. Applied Economics, 42(15), 1941-1953. doi:10.1080/00036840701749019.

Czarnitzki, D., \& Toole, A. (2011). Patent protection, market uncertainty, and R\&D investment. The Review of Economics and Statistics, 93(1), 147-159. doi:10.1162/REST_ a_00069.

De Massis, A., Di Minin, A., \& Frattini, F. (2015a). Familydriven innovation: Resolving the paradox in family firms. California Management Review, 58(1), 1-14. doi:10.1525/ cmr.2015.58.1.5.
De Massis, A., Frattini, F., \& Lichtenthaler, U. (2013). Research on technological innovation in family firms: Present debates and future directions. Family Business Review, 26(1), 10-31. doi:10.1177/0894486512466258.

De Massis, A., Frattini, F., Pizzurno, E., \& Cassia, L. (2015b). Product innovation in family versus nonfamily firms: An exploratory analysis. Journal of Small Business Management, 53(1), 1-36. doi:10.1111/jsbm.12068.

De Massis, A., Kotlar, J., Chua, J. H., \& Chrisman, J. J. (2014). Ability and willingness as sufficiency conditions for family-oriented particularistic behavior: Implications for theory and empirical studies. Journal of Small Business Management, 52(4), 344-364. doi:10.1111/jsbm.12102.

De Massis, A., Kotlar, J., Frattini, F., Chrisman, J., \& Nordqvist, M. (2016). Family governance at work: Organizing for new product development in family SMEs. Family Business Review, 29(2), 189-213. doi:10.1177/0894486515622722.

Duysters, G., \& Lokshin, B. (2011). Determinants of alliance portfolio complexity and its effect on innovative performance of companies. Journal of Product Innovation Management, 28(4), 570-585. doi:10.1111/j.1540-5885. 2011.00824.x.

Eisenhardt, K. M., \& Martin, J. A. (2000). Dynamic capabilities: What are they? Strategic Management Journal, 21(10/11), 1105-1121. doi:10.1002/1097-0266(200010/11)21:10/ $11<1105$ :AID-SMJ133>3.0.CO;2-E.

Faems, D., Van Looy, B., \& Debackere, K. (2005). Interorganizational collaboration and innovation: Toward a portfolio approach. Journal of Product Innovation Management, 22(3), 238-250. doi:10.1111/j.0737-6782.2005.00120.x.

Feito-Ruiz, I., \& Menéndez-Requejo, S. (2010). Family firm mergers and acquisitions in different legal environments. Family Business Review, 23(1), 60-75. doi:10.1177/ 0894486509353419.

Freeman, J., \& Engel, J. S. (2007). Models of innovation: Startups and mature corporations. California Management Review, 50(1), 94-119.

Greve, H. R. (1999). The effect of core change on performance: Inertia and regression toward the mean. Administrative Science Quarterly, 44(3), 590-614. doi:10.2307/2666963.

Hall, A., Melin, L., \& Nordqvist, M. (2001). Entrepreneurship as radical change in the family business: Exploring the role of cultural patterns. Family Business Review, 14(3), 193-208. doi:10.1111/j.1741-6248.2001.00193.x.

Hannan, M. T., \& Freeman, J. (1989). Organizational ecology. Cambridge: Harvard University Press.

Hatum, A., \& Pettigrew, A. (2004). Adaptation under environmental turmoil: Organizational flexibility in family-owned firms. Family Business Review, 17(3), 237-258. doi:10. 1111/j.1741-6248.2004.00016.x.

Hu, L., \& Bentler, P. M. (1998). Fit indices in covariance structure modeling: Sensitivity to underparameterized model misspecification. Psychological Methods, 3(4), 424-453. doi:10.1037/1082-989X.3.4.424.

Kelley, D. (2009). Adaptation and organizational connectedness in corporate radical innovation programs. Journal of Product Innovation Management, 26(5), 487-501. doi:10. 1111/j.1540-5885.2009.00676.x.

Klingebiel, R., \& Rammer, C. (2014). Resource allocation strategy for innovation portfolio management. Strategic 
Management Journal, 35(2), 246-268. doi:10.1002/smj. 2107.

Kotlar, J., De Massis, A., Fang, H., \& Frattini, F. (2014a). Strategic reference points in family firms. Small Business Economics, 43(3), 597-619. doi:10.1007/s11187-0149556-6.

Kotlar, J., Fang, H., De Massis, A., \& Frattini, F. (2014b). Profitability goals, control goals, and the R\&D investment decisions of family and nonfamily firms. Journal of Product Innovation Management, 31(6), 1128-1145. doi:10. 1111/jpim. 12165.

Kotter, J. P. (1995). Leading change: Why transformation efforts fail. Harvard Business Review, 73(2), 59-67.

Laursen, K., \& Salter, A. (2006). Open for Innovation: The role of openness in explaining innovative performance among UK manufacturing firms. Strategic Management Journal, 27(2), 131-150. doi:10.1002/smj.507.

Leiponen, A., \& Helfat, C. E. (2010). Innovation objectives, knowledge sources, and the benefit of breadth. Strategic Management Journal, 31(2), 224-236. doi:10.1002/smj. 807.

López-Gracia, J., \& Sánchez-Andújar, S. (2007). Financial structure of the family business: Evidence from a group of small Spanish firms. Family Business Review, 20(4), 269-287. doi:10.1111/j.1741-6248.2007.00094.x.

Miles, R. E., Snow, C. C., Fjeldstad, Ø. D., Miles, G., \& Lettl, C. (2010). Designing organizations to meet 21 st-century opportunities and challenges. Organizational Dynamics, 39(2), 93-103. doi:10.1016/j.orgdyn.2010.01.009.

Miller, D., Le Breton-Miller, I., \& Lester, R. H. (2011). Family and lone founder ownership and strategic behavior: Social context, identity, and institutional logics. Journal of Management Studies, 48(1), 1-25. doi:10.1111/j.14676486.2009.00896.x.

Muñoz-Bullón, F., \& Sanchez-Bueno, M. J. (2011). The impact of family involvement on the R\&D intensity of publicly traded firms. Family Business Review, 24(1), 62-70. doi:10.1177/0894486510396870.

Naldi, L., Nordqvist, M., Sjoberg, K., \& Wiklund, J. (2007). Entrepreneurial orientation, risk taking, and performance in family firms. Family Business Review, 20(1), 33-47. doi:10.1111/j.1741-6248.2007.00082.x.

Norman, G. R., \& Streiner, D. L. (2003). PDQ Statistics. BC Decker, Ontario.

OECD and Eurostat. (2005). Oslo Manual: Guidelines for Collecting and Interpreting Innovation Data (3rd ed.). Paris: OECD Publications.

Pakes, A., \& Griliches, Z. (1980). Patents and R\&D at the firm level: A first report. Economics Letters, 5(4), 377-381. doi:10.1016/0165-1765(80)90136-6.

Patel, P. C., \& Chrisman, J. J. (2014). Risk abatement as a strategy for R\&D investments in family firms. Strategic Management Journal, 35(4), 617-627. doi:10.1002/smj. 2119.

Raynor, M., \& Ahmed, M. (2013). The three rules. How exceptional companies think. Portfolio: Penguin.
Reichers, A. E., Wanous, J. P., \& Austin, J. T. (1997). Understanding and managing cynicism about organizational change. Academy of Management Executive, 11(1), 48-59. doi:10.5465/AME.1997.9707100659.

Rosenberg, N. (1990). Why do firms do basic research (with their own money)? Research Policy, 19(2), 165-174. doi:10.1016/0048-7333(90)90046-9.

Schmid, T., Achleitner, A.-K., Ampenberger, M., \& Kaserer, C. (2014). Family firms and R\&D behavior-New evidence from a large-scale survey. Research Policy, 43(1), 233-244. doi:10.1016/j.respol.2013.08.006.

Schneider, C., \& Veugelers, R. (2010). On young highly innovative companies: Why they matter and how (not) to policy support them. Industrial and Corporate Change, 19(4), 969-1007. doi:10.1093/icc/dtp052.

Sciascia, S., Nordqvist, M., Mazzola, P., \& De Massis, A. (2015). Family ownership and R\&D intensity in small and medium-sized firms. Journal of Product Innovation Management, 32(3), 349-360. doi:10.1111/jpim.12204.

Sharma, S. (1996). Applied multivariate techniques. New York: Wiley.

Sharma, P., \& Irving, P. G. (2005). Four bases of family business successor commitment: Antecedents and consequences. Entrepreneurship Theory and Practice, 29(1), 13-33. doi:10.1111/j.1540-6520.2005.00067.x.

Shi, C. (2003). On the trade-off between the future benefits and riskiness of R\&D: A bondholders' perspective. Journal of Accounting and Economics, 35(2), 227-254. doi:10.1016/ S0165-4101(03)00020-X.

Sirmon, D. G., \& Hitt, M. A. (2003). Managing resources: Linking unique resources, management and wealth creation in family firms. Entrepreneurship Theory and Practice, 27(4), 339-358. doi:10.1111/1540-8520.t01-1-00013.

Spithoven, A., Frantzen, D., \& Clarysse, B. (2010). Heterogeneous firm-level effects of knowledge exchanges on product innovation: Differences between dynamic and lagging product innovators. Journal of Product Innovation Management, 27(3), 362-381. doi:10.1111/j.1540-5885.2010. 00722.x.

Steier, L. P., \& Miller, D. (2010). Pre- and post-succession governance philosophies in entrepreneurial family firms. Journal of Family Business Strategy, 1(3), 145-154. doi:10.1016/j.jfbs.2010.07.001.

Teece, D. J., Pisano, G., \& Shuen, A. (1997). Dynamic capabilities and strategic management. Strategic Management Journal, 18(7), 509-533. doi:10.1002/(SICI)1097-0266(199708)18: 7<509:AID-SMJ882>3.0.CO;2-Z.

Zahra, S. A., Hayton, J. C., Neubaum, D. O., Dibrell, C., \& Craig, J. (2008). Culture of family commitment and strategic flexibility: The moderating effect of stewardship. Entrepreneurship Theory and Practice, 32(6), 1035-1054. doi:10.1111/j.1540-6520.2008.00271.x.

Zellweger, T. M. (2007). Time horizon, costs of equity capital, and generic investment strategies of firms. Family Business Review, 20(1), 1-15. doi:10.1111/j.1741-6248.2007.000 80.x. 